EESTI NSV TEADUSTE AKADEEMIA TOIMETISED 1955. IV kd., nr. 2 ИЗВЕСТИЯ АКАДЕМИИ НАУК ЭСТОНСКОИ ССР 1955. Том IV, № 2

\title{
ОСНОВНЫЕ ЧЕРТЫ ГЕОЛОГИЧЕСКОГО РАЗВИТИЯ ТЕРРИТОРИИ ЭСТОНСКОЙ ССР В АНТРОПОГЕНОВОМ ПЕРИОДЕ.
}

\author{
К. К. ОРВИКУ, \\ действительный член Академии наук Эстонской ССР
}

При решении многих задач народного хозяйства необходимо учитывать геологическое строение и развитие территории в антропогеновом периоде. Возведение разных сооружений, проведение мелиоративных работ, решение вопросов водоснабжения и т. д. невозможно без детального изучения отложений и форм рельефа антропогенового периода. Многие из антропогеновых отложений, например глина, торф, пески, озерный мел и др., являются полезными ископаемыми, которые широко используются для удовлетворения нужд народного хозяйства республики. Проведению соответствующих геологосъемочных и геологоразведочных работ значительно способствует знание закономерностей распределения и геологического развития отложений и форм рельефа антропогенового периода. В настоящей статье рассматриваются некоторые наиболее существенные из этих закономерностей.

Геологическое строение и развитие территории Эстонской ССР в антропогеновом периоде в общих чертах выяснено многими работами, проведенными в последние десятилетия.,Особенно много нового ценного материала дали работы последних лет. Они позволили более полно охарактеризовать основные закономерности распределения и развития отложений и форм рельефа антропогенового периода на территории Әстонии.

В течение антропогенового периода на территории Эстонской ССР образовались различные по происхождению и возрасту отложения и формы рельефа. Большое распространение имеют здесь образования материкового льда, отложения и формы рельефа морского происхождения, образования текущих вод, эоловые отложения и формы рельефа, часто встречаются карстовые образования и т. д.

Большинство этих отложений и форм рельефа образовались в течение голоценовой эпохи антропогенового периода, в то время как плейстоценовые образования представлены в основном ледниковыми отложениями и формами рельефа валдайского века верхнего плейстоцена. Сравнительно мало фактического материала известно с территории Эстонии о среднеплейстоценовых отложениях и формах рельефа; образования же нижнего плейстоцена здесь пока не известны. Поскольку на смежных территориях, где плейстоценовые отложения представлены лучше, установлено трехкратное чередование условий материкового льда с условиями континентальных и морских геологических процессов, то можно предполагать, что 
такое же чередование геологических процессов происходило в плейстоцене и на территории Эстонской ССР. Причиной такой смены условий считают значительные колебания климата.

По меньшей мере трехкратное ухудшение климатических условий в плейстоцене, обусловившее распространение материкового льда на территорию республики, имело большое влияние и на ее геологическое развитие: с каждым новым продвижением материкового льда прекращалось влияние континентальных и морских геологических процессов, а ранее образовавшиеся отложения и формы рельефа были большей частью снесены и уничтожены новым материковым льдом.

Палинологическими исследованиями установлено, что и в голоцене климат на территории республики значительно изменился - с освобождением территории от ледникового покрова последнего оледенения началось улучшение климата, которое достигло своего максимума в среднем голоцене; в позднем голоцене снова замечается ухудшение климата. Изменение в голоцене климатических условий, несомненно, имело влияние на интенсивность протекающих здесь в то время геологических процессов.

На геологическое развитие имела большое влияние деятельность материкового льда последнего ледникового века. Достаточно указать, что большая часть из тех отложений антропогенового периода, которые прикрывают коренные породы, а также многие формы рельефа, оказывающие значительное влияние на общее развитие природных условий, образовались в течение последнего ледникового века. Нет необходимости более подробно останавливаться на таких общеизвестных вопросах, как роль морены в режиме поверхностных и подземных вод, в образовании озер, в развитии болот и почв. Также общеизвестно влияние холмисто-моренного или друмлинового рельефа на распределение и развитие природных условий в голоцене. Под действием материкового льда последнего ледникового века образовывались и накоплялись такие полезные ископаемые, как гравийные материалы и пески, глины, эрратические валуны, которые являются ценным сырьем для местной строительной промышленности. Отложения и формы рельефа последнего оледенения необходимо учитывать при проведении разного рода инженерно-геологических работ.

Но в то же время накопляется новый материал, который говорит о том, что на территории Эстонской ССР встречаются в значительном объеме плейстоценовые отложения, образование которых произошло раньше последнего ледникового века, Отмечается все больше случаев установления подморенных флювиогляциальных отложений, а также более древних морен, которые имеют большое распространение, в частности в границах холмисто-моренного рельефа. Это позволило поднять вопрос о том, не имеют ли эти подморенные отложения рельефообразующее значение в холмисто-моренном рельефе.

В распространении отложений и форм рельефа последнего ледникового века на территории Эстонской ССР устанавливается определенная закономерность.

Уже в двадцатых годах нашего века было проведено подразделение территории Эстонии на три зоны, характеризующиеся определенными ледниковыми отложениями и формами рельефа последнего оледенения (рис. 1).

На юго-востоке выделяется зона распространения холмисто-моренного рельефа. В северо-западном направлении эту зону окаймляет полудугой зона друмлиновых полей. Последняя в свою очередь ограничена зоной преобладания моренных равнин, краевых образований и озовых систем.

Выяснению причин такого закономерного распространения образований последнего оледенения не уделялось должного внимания. Несомненно, 


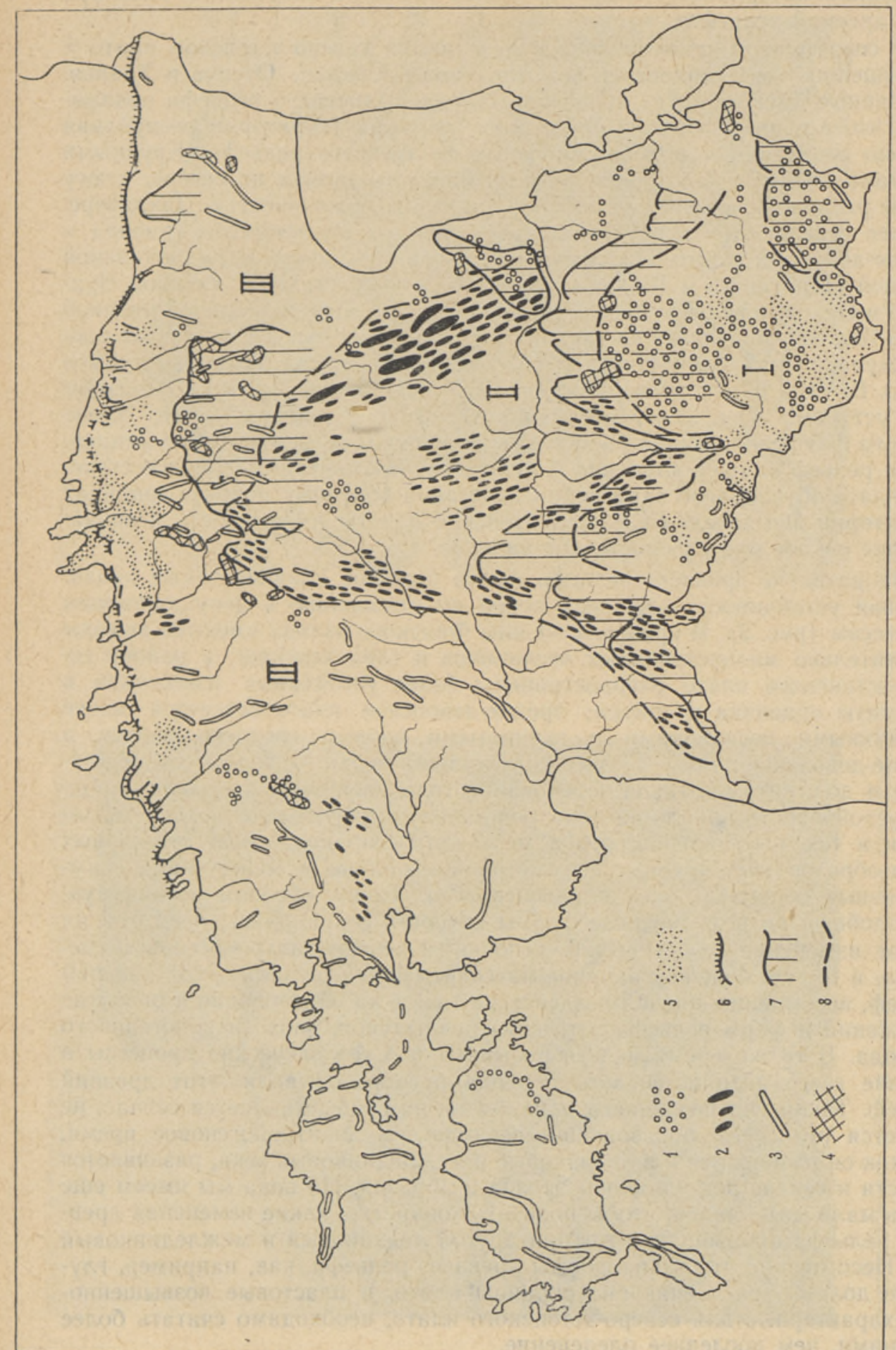

음

ㅇํㅇ

言।

1

(2)

월

之西

똥응

붕으

票 $x$

ํํㄹ

*

호융 뚱

$=\bar{\Omega}$

芯 뜰

立 焉三

응

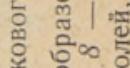

ए व्र

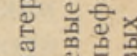

$\sum$ d

苟 $x$

है। 닐

次要

送至

응 홍

플 일

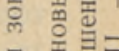

= 票二

ํ.

产 合

ह $1 N$

Nㅇㅇㅛ

름 얼일

-

-

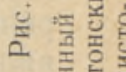

娄

은

5월

产

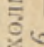

$1 \frac{5}{5}$ 
что одной из причин такой зональности является характер отступания последнего материкового льда. Но особое значение, безусловно, имел при этом древний рельеф.

В современном рельефе четко выделяются северо-эстонское плато с возвышенностью Пандивере, возвышенности Сакала, Отепяа и Хаанья, отделенные друг от друга низинами. Изучение древнего рельефа показывает, что крупные формы современного рельефа территории республики хорошо совпадают с подобными формами древнего рельефа. Крупными формами последнего является низина Финского залива на севере; к югу от нее расположено северо-эстонское плато с возвышенностью Пандивере. Южнее северо-эстонского плато находится средне-эстонская низина и средне-девонское плато. Последнее на западе ограничено меридиональной низиной Пярнуского и Рижского заливов, а на востоке - низиной Чудского и Псковского озер; средне-девонское плато меридиональной низиной озера Выртсъярв делится на западную и восточную части. Еще южнее расположена низина Выру-Пиуза и на самом юго-востоке верхне-девонское плато. Все три плато с севера ограничены более или менее ясно выраженным уступом. Так, северной границей северо-эстонского плато вдоль южного побережья Финского залива является глинт, в южном же направлении рельеф плато постепенно понижается. Такое несимметричное строение плато обусловлено характером залегания коренных пород в границах территории Эстонской ССР: полеозойские пласты имеют здесь незначительное южное или юго-восточное падение.

На развитие древнего рельефа имела большое влияние также неодинаковая устойчивость коренных пород по отношению к денудационным процессам (рис. 2). В пределах низины Финского залива имеются выходы сравнительно малоустойчивых песчаников и глин кембрия; в районе северо-эстонского плато распространены более устойчивые известняки и доломиты ордовика и силура; средне-девонское плато слагается менее устойчивыми песчаниками и глинистыми слоями среднего девона, а ьерхне-девонское плато - более устойчивыми верхне-девонским известняками и доломитами. Такое чередование толщ коренных пород разнородной устойчивости влияло на доантропогеновую длительную эрозию территории в том направлении, что в местах простирания менее устойчивых толщ образовались крупные асимметричные долины, а между ними асимметричные водораздельные возвышенности. Таким образом возник куэстоподобный рельеф, крупные формы которого сохранились, несмотря на резкое изменение геологических условий в течение антропогенового периода, и имеют большое влияние на современный рельеф. Әтот древний рельеф, несомненно, оказал воздействие также на образование и развитие отложений и форм рельефа в течение предыдущих эпох антропогенового периода. В то же время нельзя забывать, что геологические процессы в течение всего антропогенового периода-преобразовывали этот древний рельеф. Такой вид последнего, в каком он нам представляется сейчас, не является рельефом, образовавшимся только в доантропогеновое время, так как он развивался и в ледниковые и межледниковые века, развивается отчасти и сейчас под влиянием эрозии и абразии. Но пока мы имеем еще очень мало материалов, чтобы показать конкретно, какие изменения древнего рельефа произошли в тот или другой ледниковый и межледниковый век. Несомненно, что такие формы древнего рельефа, как, например, глубокие долины, расчленяющие окраины плато, и пластовые возвышенности, характерные для северо-эстонского плато, необходимо считать более древними, чем последнее оледенение.

На распространение отложений и форм рельефа последнего оледенения оказали влияние крупные формы древнего рельефа. Холмисто-морен- 


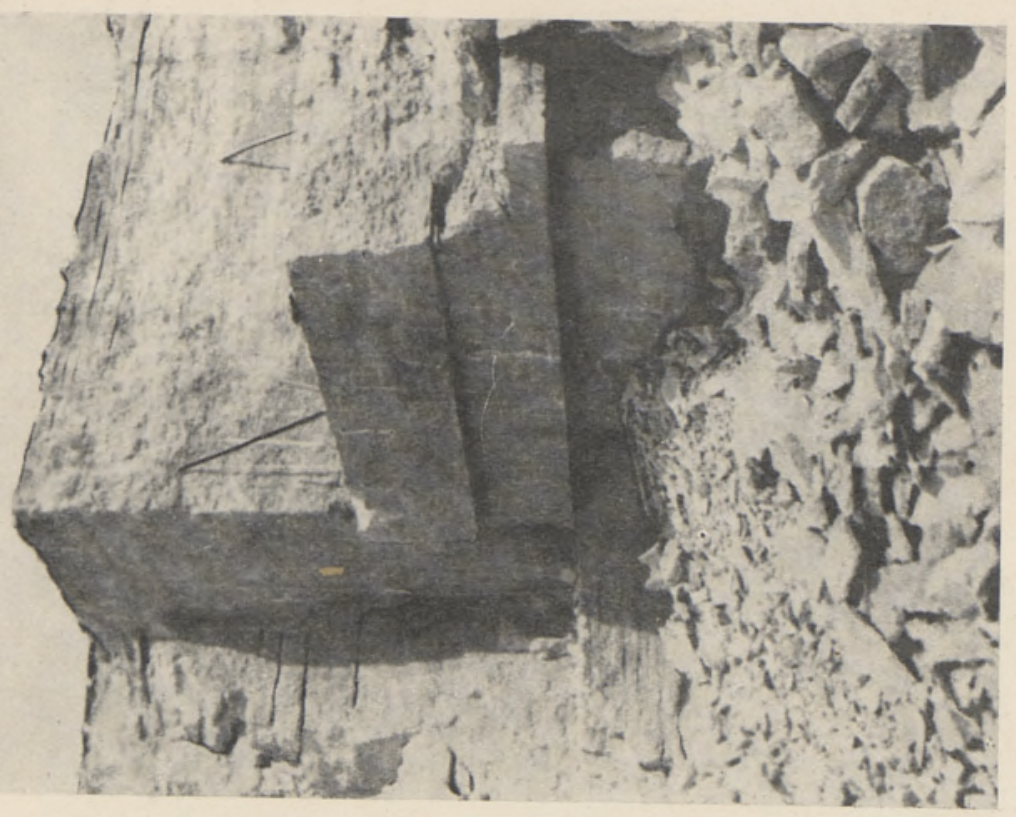

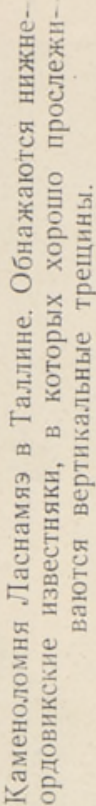
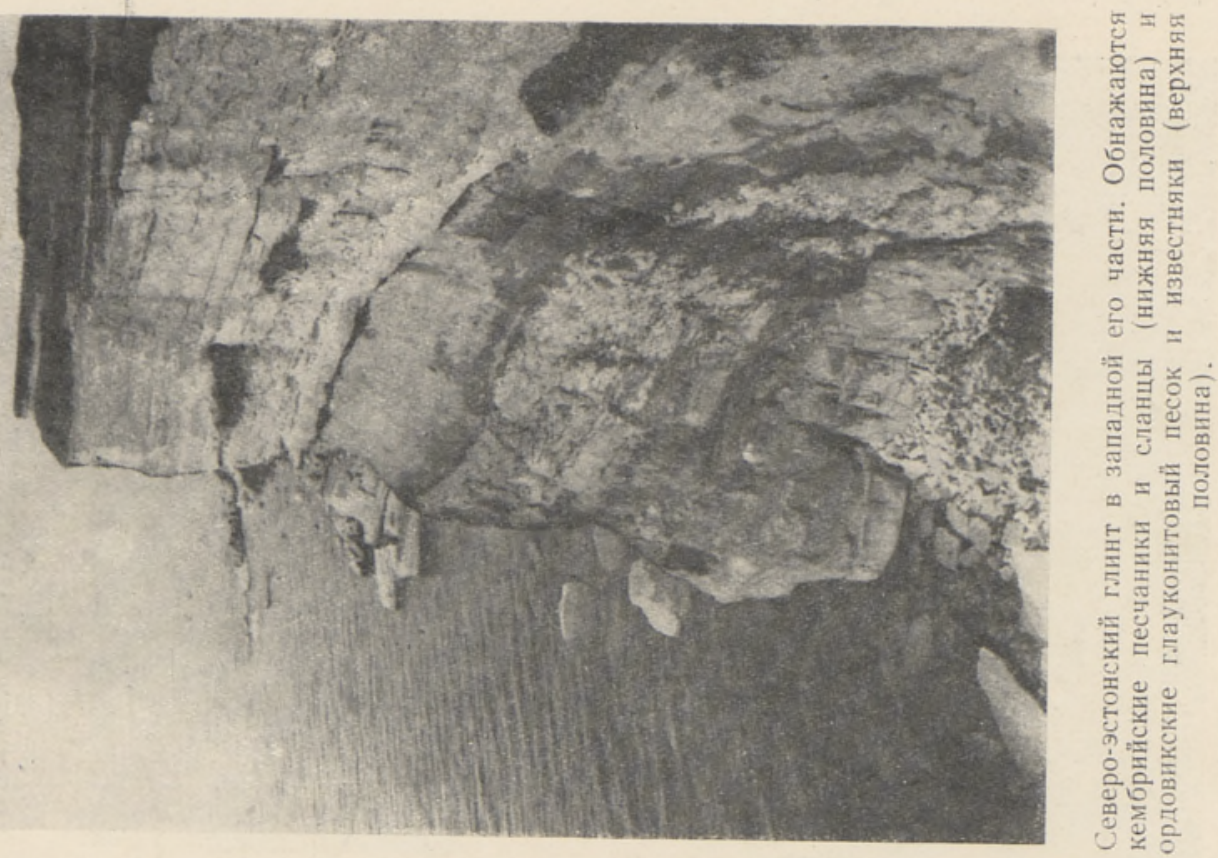

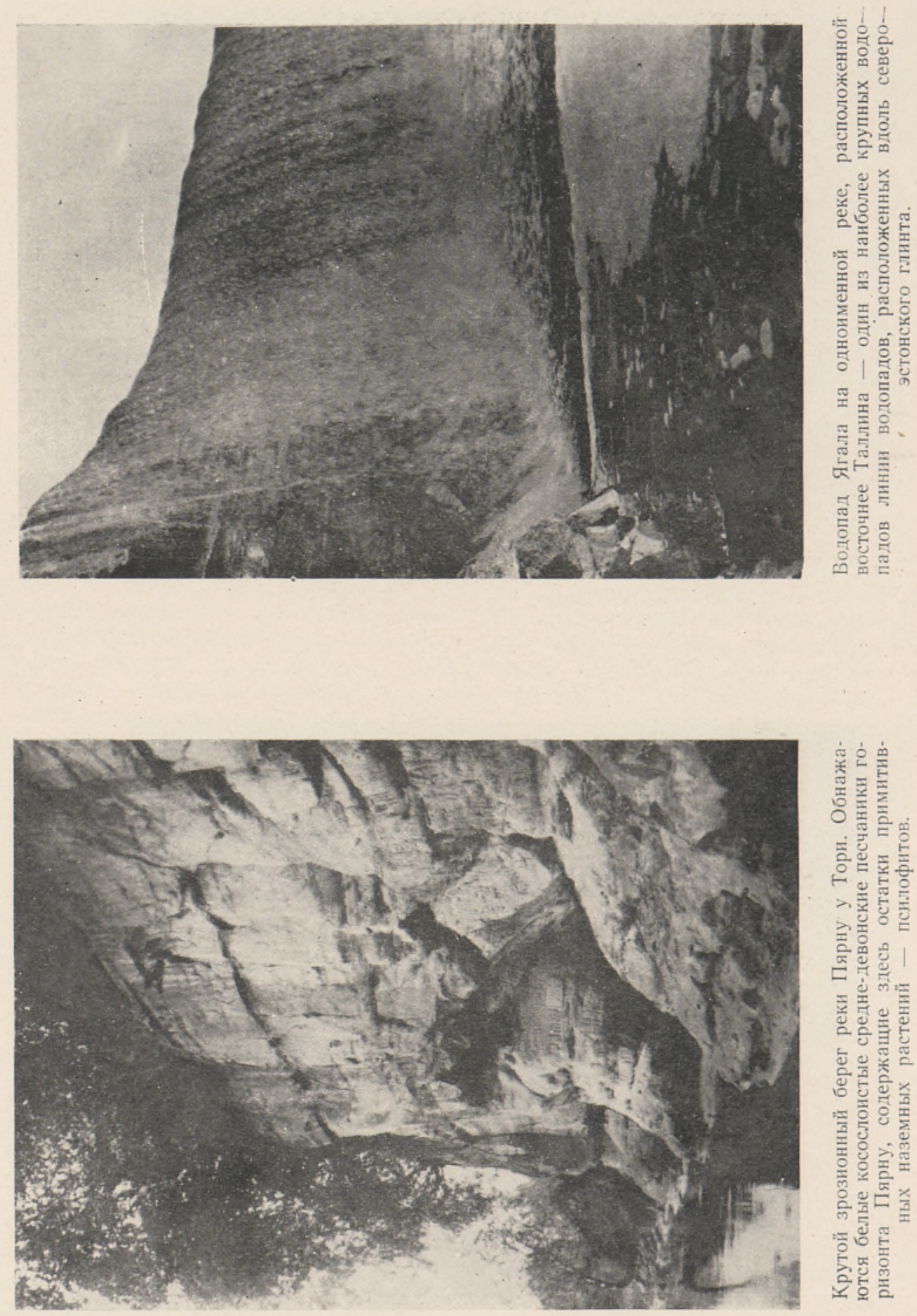


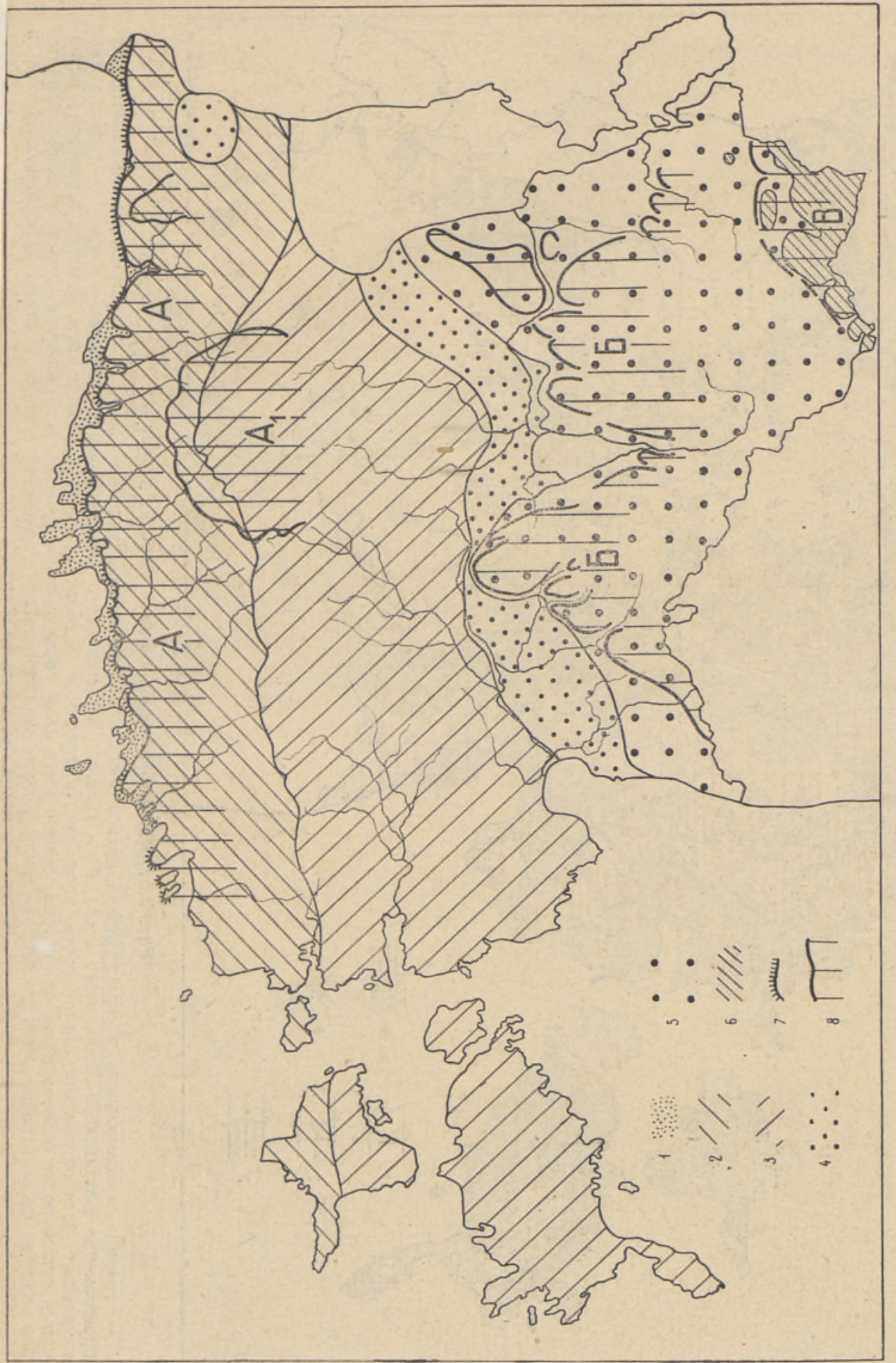

琣的 急 $=$ 哓焉

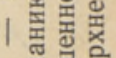
廿 获署 ๙ 函品 ब.

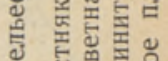

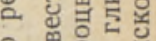
을 ह1잉

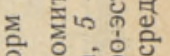
६ $\times$ 훙

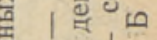
ํํำ 过示

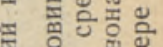

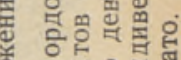
종밍일 5 통 칟은웜옥

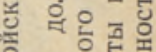

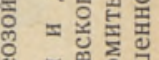
\&

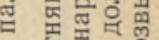
导 $=$ 的 줄 이이

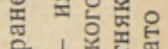

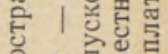

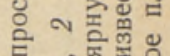
등 的受

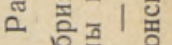

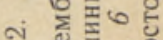
-

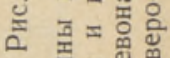
沓总 $=$ 잉 동 줒 험.. 㑢议 要要 $=$ 임율 1 它它。 


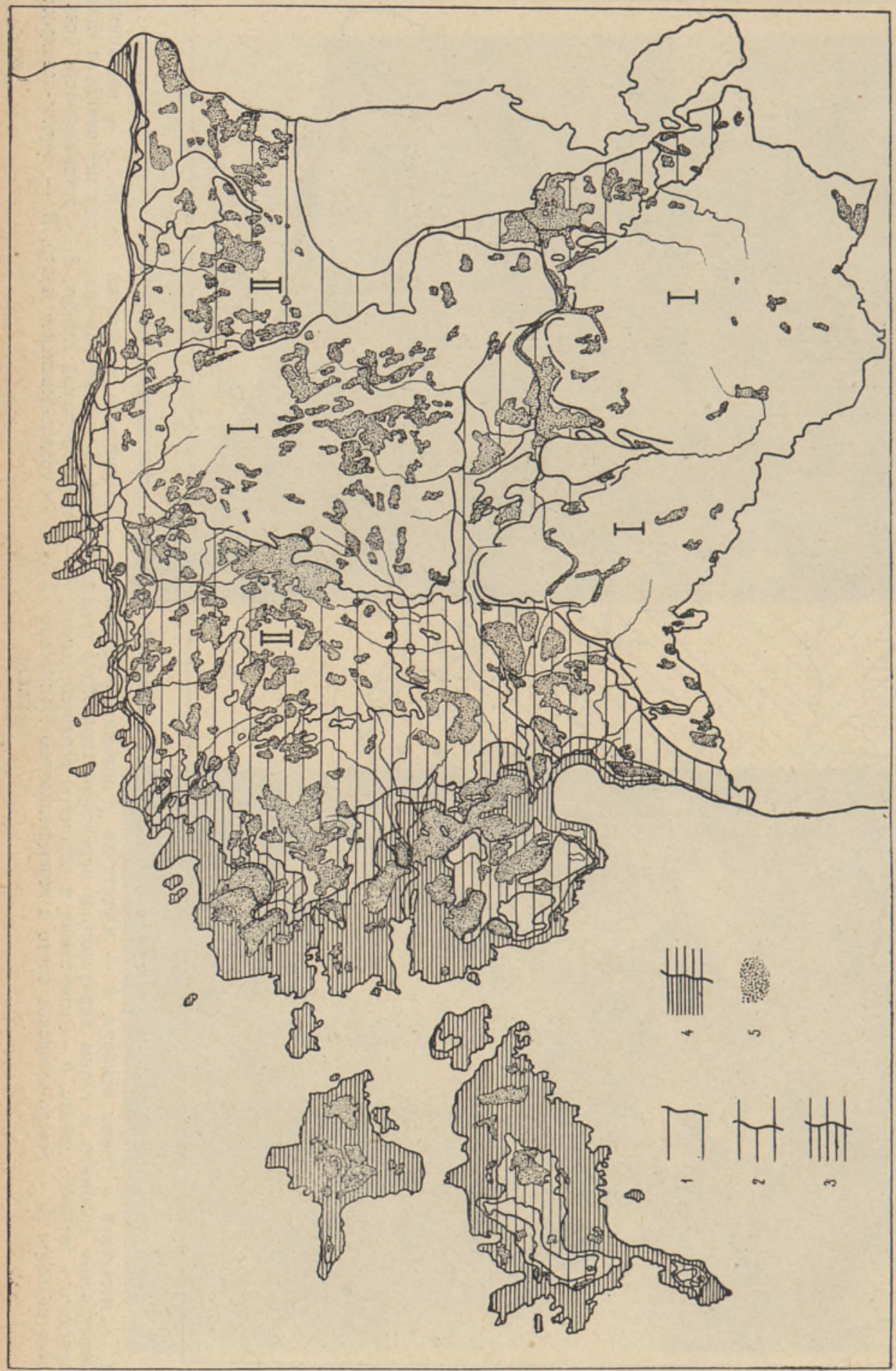

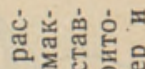

잉

능

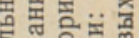

전은토풍

출 흥핲

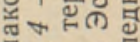

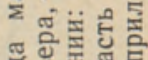

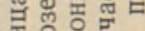

플

는 똪

|

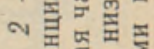

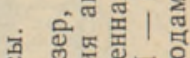

政

응 줄

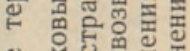

일

흥 댄

달.

= 흘온잉인

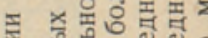

눌

议

- $\Sigma$ U.

중

的

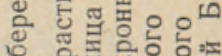

\&

着

总 ।

的的然

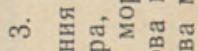

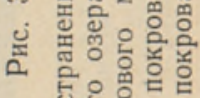

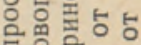

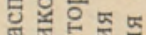

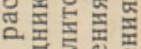

인

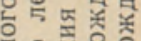

푹은 풜융융

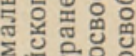

츤 잉ㅇ

퉁은

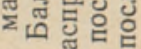

뜰

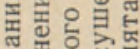

는퓸의

릉

1 

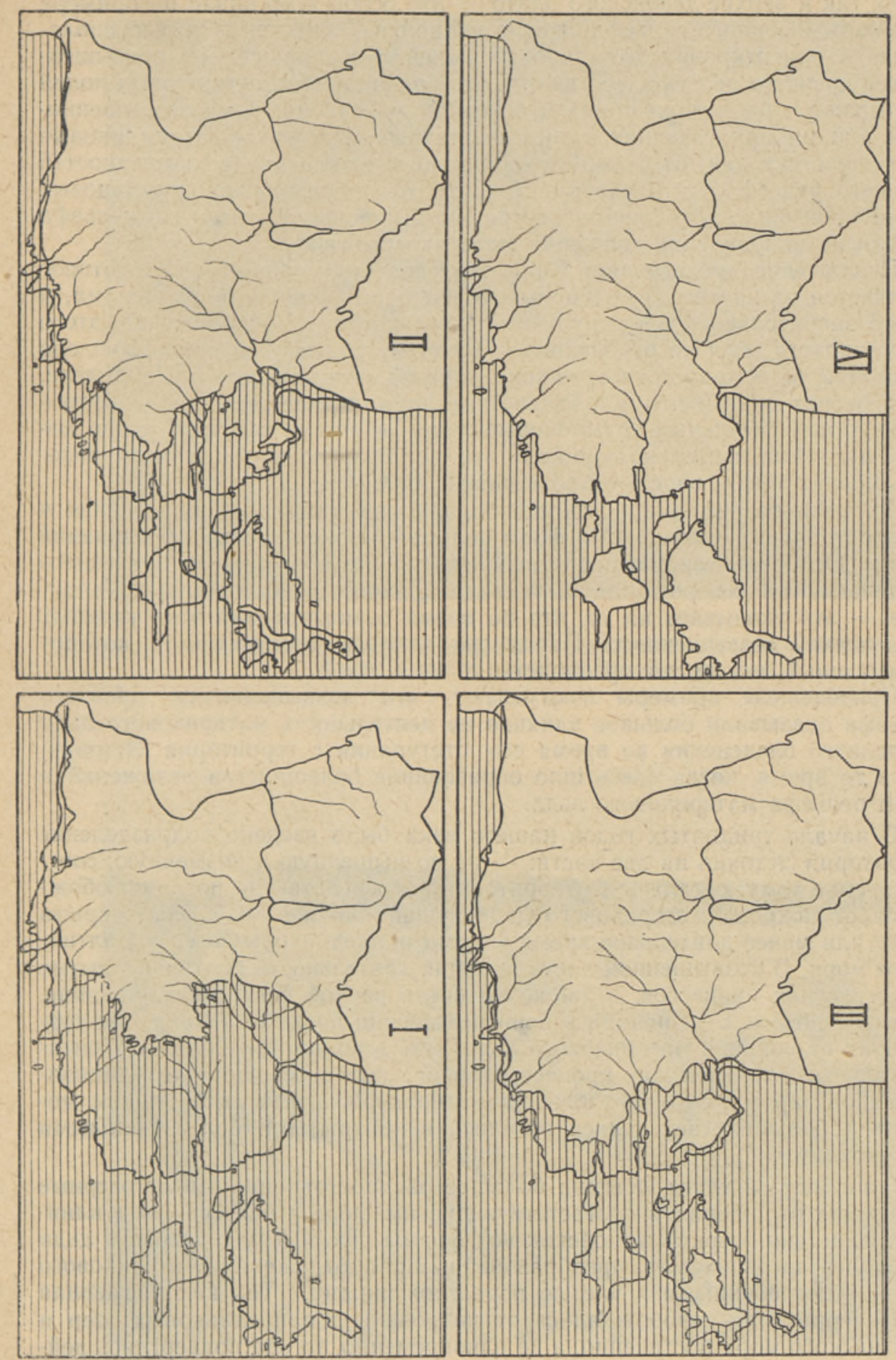

10



离।

这

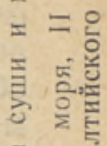

刃ำ

을

记

-

+ ตึ้

政

흥

옹옽

등

悋

음

임

=

䆓容

을

สำ

产

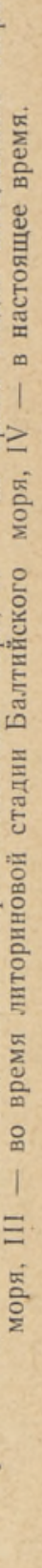


ный рельеф характерно развит в центральных частях как средне-девонского, так и верхне-девонского плато - это особо ясно видно на примере холмисто-моренного рельефа Отепяа и Хаанья. Если сопоставим расположение и ориентировку друмлиновых полей с расположением возвышенностей древнего рельефа, то увидим, что большинство друмлиновых полей оказываются расположенными в основном на склонах этих возвышенностей или на прилегающих к ним равнинных участках - друмлиновые поля являются как бы формами обтекания в отношении возвышенностей древнего рельефа. Это указывает на то, что образование друмлиновых полей произошло в то время, когда возвышенности древнего рельефа влияли на направление движения материкового льда.

Исключение представляет Саадъярвеское друмлиновое поле, которое отличается от других друмлиновых полей более крупными размерами, а также значительно более крупными друмлинами. Расположение этого друмлинового поля по отношению к древнему рельефу своеобразное: оно находится на юго-восточном склоне древней возвышенности Пандивере. Это говорит о том, что Саадъярвеское друмлиновое поле образовалось раньше, чем остальные друмлиновые поля, - еще в то время, когда покров льда был настолько мощным, что мог при своем движении преодолеть препятствие в виде этой возвышенности.

Древний рельеф имел, несомненно, влияние также на образование и распространение отложений и форм рельефа в зоне краевых образований и озов. Особенно хорошо представлены краевые образования последнего оледенения на северо-западном склоне древней возвышенности Пандивере - это указывает на то, что во время возникновения этих краевых образований возвышенность Пандивере явилась препятствием, которое материковый лед не мог преодолеть.

Приведенные примеры показывают, -что возвышенности древнего рельефа оказывали большое влияние на деятельность материкового льда последнего оледенения во время его отступания с территории Эстонии, т.е. в то время, когда здесь шло образование большинства отложений и форм рельефа материкового льда.

В начале тридцатых годов нашего века было введено подразделение территории Эстонии на две части: - на возвышенную и низменную, соответственно тому, осталась ли территория непосредственно после освобождения от покрова материкового льда сушей или же она была покрыта более или менее длительное время водами приледниковых озер и Балтийского моря. В возвышенной части Әстонии деятельность континентальных геологических процессов, а также развитие речной сети, заболачивание, развитие почв и т. д. начались непосредственно после освобождения территории от покрова материкового льда, т. е. в конце плейстоцена. Континентальные геологические процессы имели здесь в основном денудационный характер и поэтому отложения материкового льда (в частности морена) в большинстве случаев остались неприкрытыми более молодыми отложениями.

В низменной части Эстонии большое распространение имеют озерные и морские отложения и соответствующие им формы рельефа; под влиянием действия озерных и морских вод формы рельефа материкового льда оказались здесь частью преобразованными, и отложения материкового льда - погребенными и частью переотложенными. Так как низменная часть территории освобождалась от покрова вод приледниковых озер и Балтийского моря постепенно, а не одновременно, то она подверглась действию континентальных геологических процессов в разных своих частях в разное время. В качестве примера можно назвать речную систему Казари, которая в древнем голоцене еще не существовала; она стала раз- 


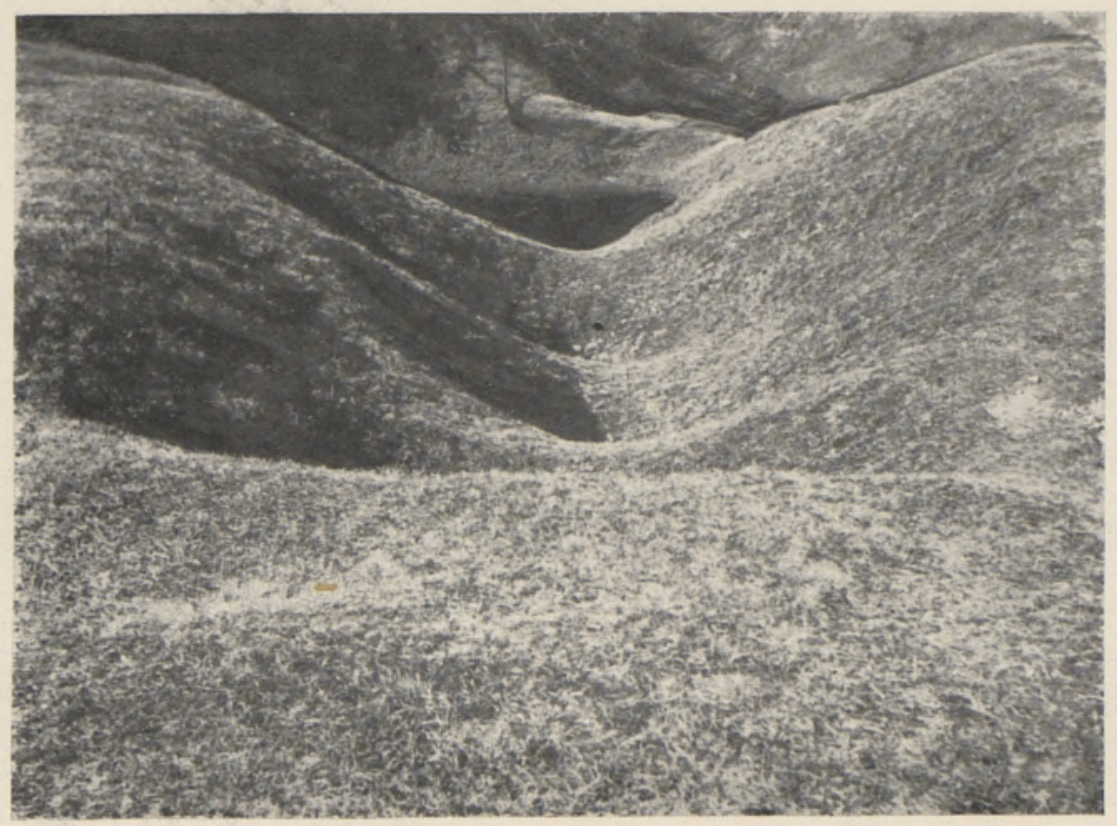

Қарстовые воронки на северо-эстонском плато в окрестностях подземной реки Ухаку, в северо-восточной Эстонии.

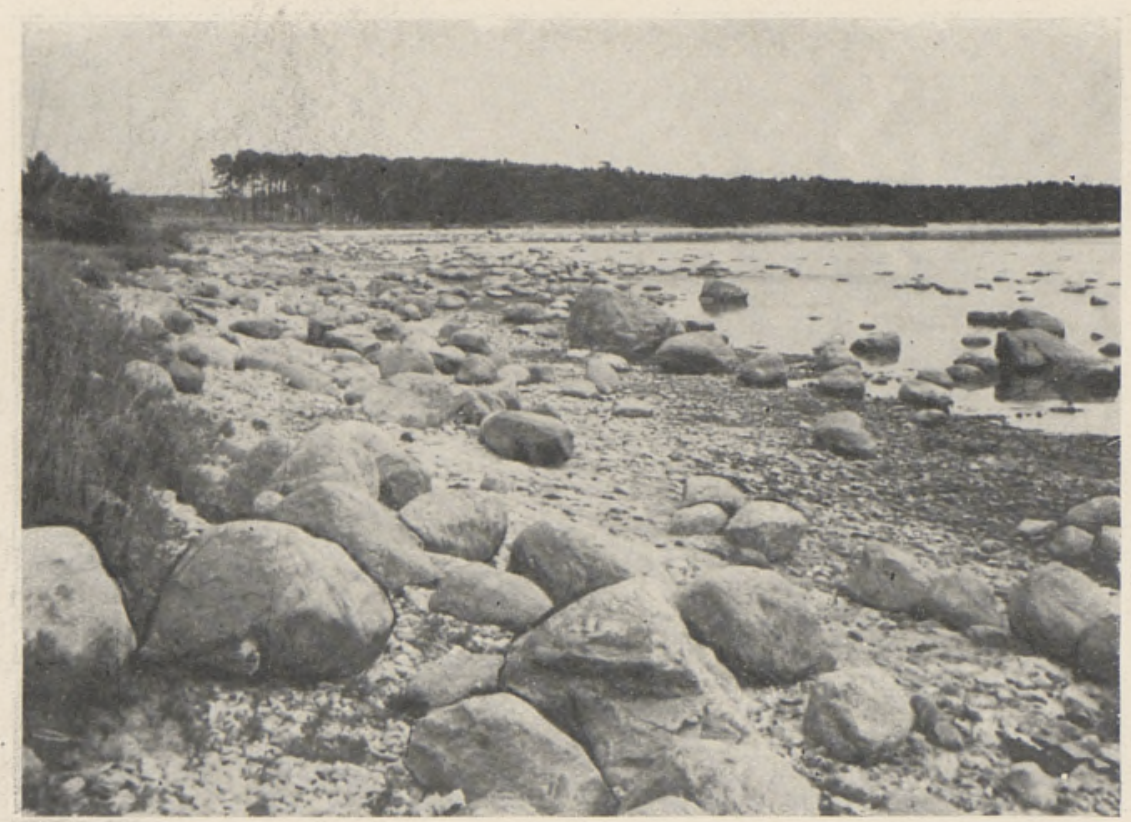

Аб́разнонный береѓ Финского залива у Меривялья, недалеко от Таллина. Характерно большое количество эрратических валунов, вымытых из морены. 


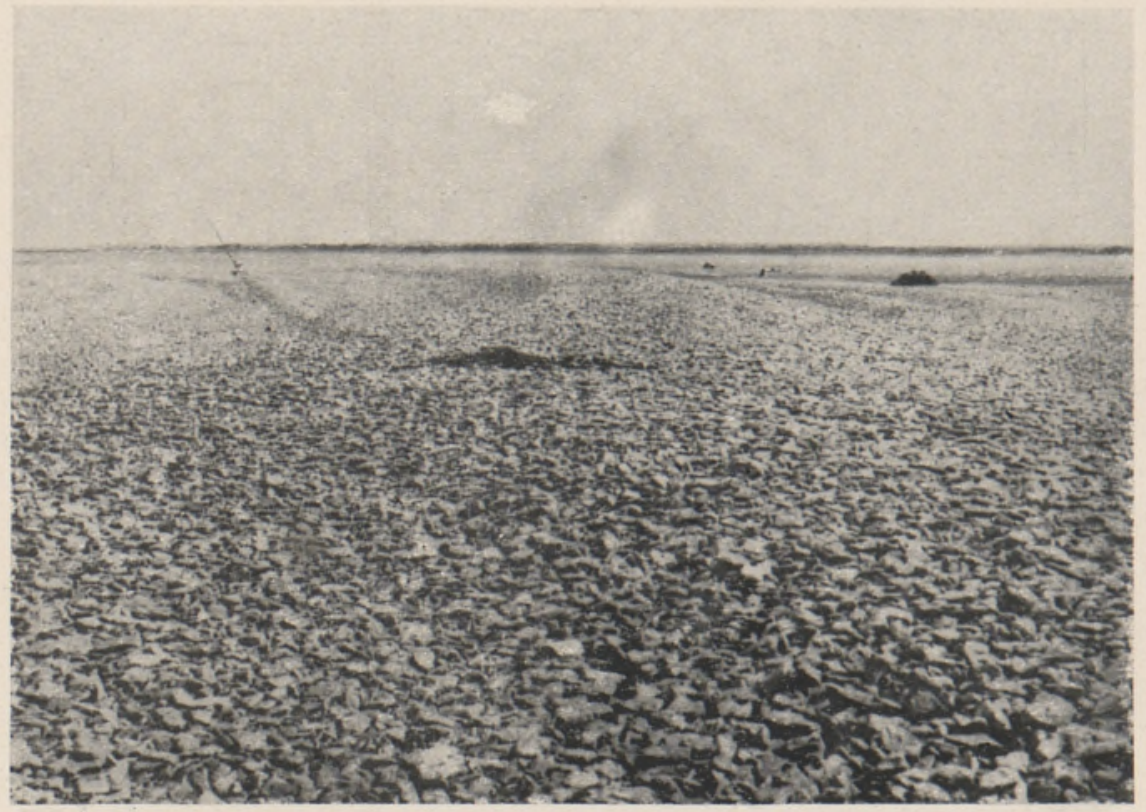

Древние незаросшие щебневые береговые валы на острове Сааремаа, спускающиеся непосредственно до современной береговой линии.

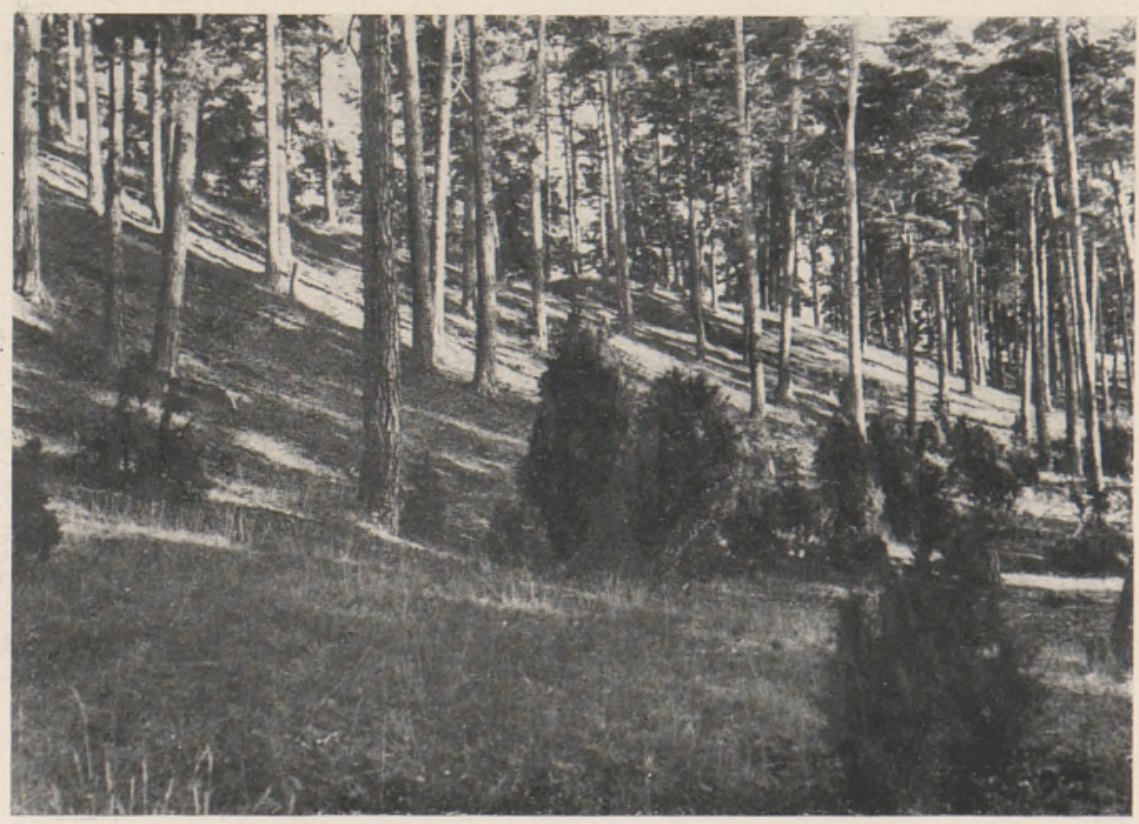

Древние заросшие берегозые дюны на острове Сааремаа, 


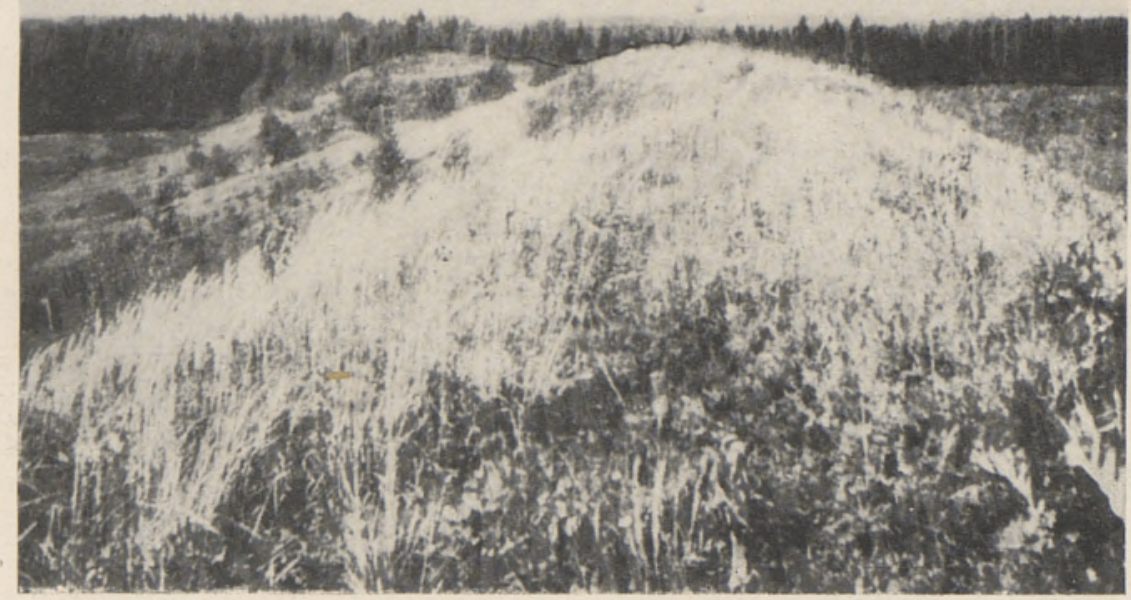

Пссчано-галечниковая озовая гряда в окрестностях Аэгвийду (северная Эстония) в границах северо-эстонской зоны краевых образований.

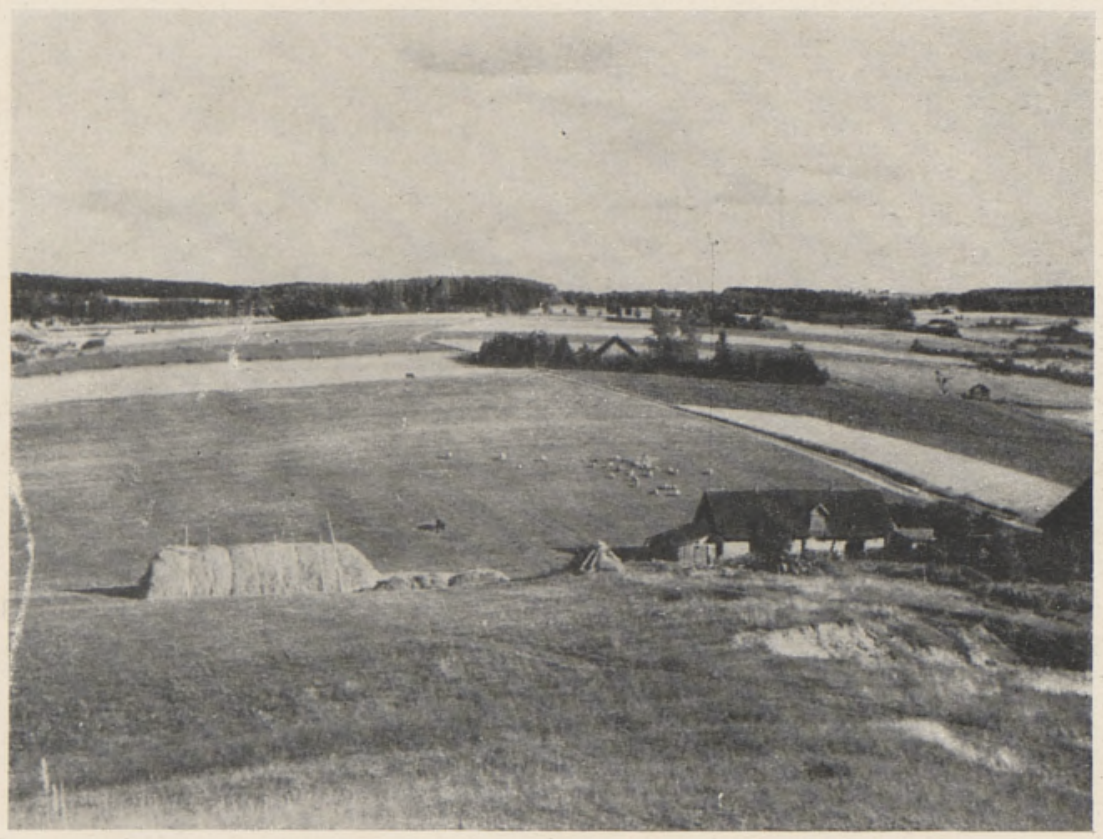

Поперечный профиль друмлина в Саадъярвеском друмлиновом поле, севернее r. Тарту. 


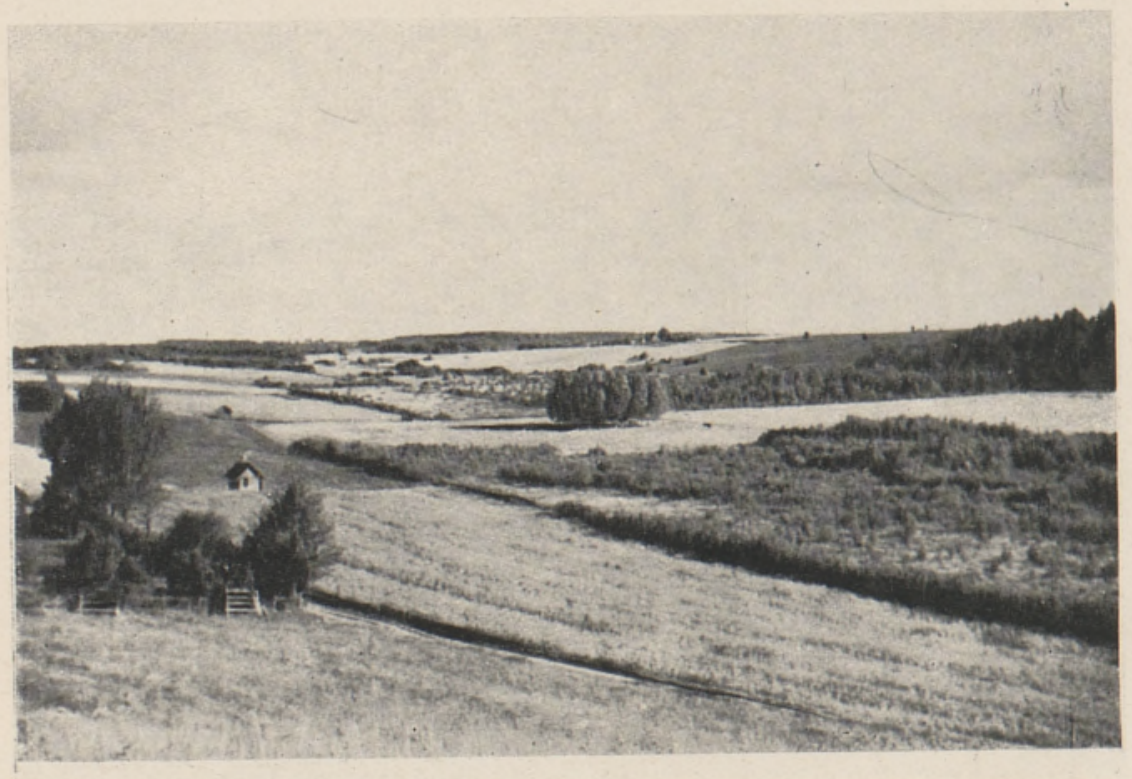

Древняя долина восточнее г. Вильянди.

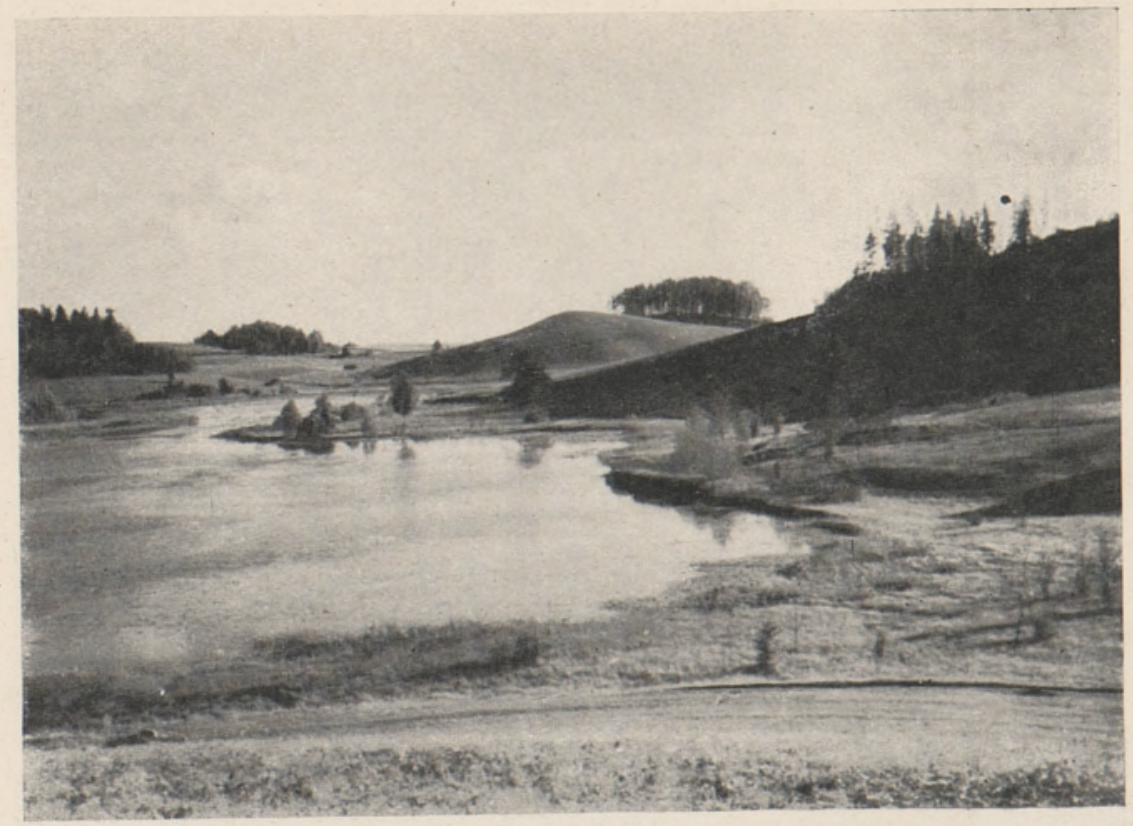

Одно из живописных озер в зоне краевых образований - Карула. 
виваться только в раннем голоцене. Еще в начале среднего голоцена реки Теэнузе, Коновере, Пярну и Энге впадали самостоятельно в Балтийское море и только позднее они слились и образовали современную реку Казари с ее притоками. Подобных примеров можно привести много. Они показывают, что в низменной части территории реки и их долины, озера, болота, карстовые формы, почвы и т. д. имеют различный возраст в зависимости от того, когда территория, на которой они находятся, освободилась от покрова вод (рис. 3 и 4). При изучении природных условий республики необходимо это учитывать.

Следует отметить также и то, что в подразделении территории Эстонии на возвышенную и низменную части большую роль играет древний рельеф: возвышенная часть территории - это в основном возвышенности древнего рельефа.

Влияние условий залегания и литологического состава коренных пород на геологическое развитие территории Эстонии в антропогеновом периоде проявляется и во многом другом. Например, то обстоятельство, что северо-эстонское плато в своей краевой полосе на севере, где его границей является глинт, расчленено долинами сравнительно слабо, обусловлено отчасти, несомненно, тем,-что северо-эстонское плато образуют известняки и доломиты ордовика и силура. В то же время средне-девонское плато расчленено долинами значительно больше, отчасти потому, что это плато слагают средне- и верхне-девонские песчаники и глинистые породы, которые более податливы эрозионным процессам, чем карбонатные породы северо-эстонского плато.

Влияние коренных пород на геологическое развитие территории в антропогеновом периоде прослеживается хорошо на северо-эстонском плато, где местами имеют большое распространение пластовые возвышенности. Пласты горизонтов ордовика и силура имеют различную, устойчивость по отношению к денудационным процессам, вследствие чего вдоль выходов более устойчивых пластов в процессе длительной денудации образовались группы небольших пластовых возвышенностей.

Надо отметить, что маломощность отложений материкового льда на северо-эстонском плато обусловлена отчасти тем, что известняки и доломиты в меньшей мере подвергались экзарации, чем кластические отложения девона в более южных частях территории.

Геологическое строение коренных пород имеет большое значение и в развитии карста. Карст на территории Эстонии сосредоточен в основном на северо-эстонском плато, где распространены трещиноватые известняки и доломиты.

При изучении древних береговых образований, представленных в Эстонии в виде многочисленных абразионных уступов и береговых валов, а также в виде береговых дюн, выяснилось, что одновозрастные древние береговые образования в северо-западной части территории имеют значительно бо́льшую абсолютную отметку, чем в юго-восточной части, в направлении которой они постепенно опускаются. Причина такого явления заключается в основном в поднятии земной коры в границах территории Әстонии в течение голоцена, причем к северо-западу поднятие возрастает, а в юго-восточном направлении интенсивность поднятия постепенно уменьшается. Эти неотектонические движения земной коры проявляются не только в перемещении береговой линии, но оказывают влияние также и на многие континентальные геологические процессы. Так, например, под влиянием уменьшения интенсивности поднятия земной коры с северозапада к юго-востоку условия глубинной эрозии в юго-восточном направлении постепенно ухудшаются, а условия накопления аллювиальных отложений и условия образования торфов низинных болот - улучшаются. 
Это показывает, что при изучении геологического развития территории в голоцене необходимо также уделять внимание роли неотектонических движений земной коры.

Нет сомнения, что и в плейстоцене на территории Эстонской ССР происходили неотектонические движения земной коры; колебания земной коры имели здесь существенное значение также в доантропогеновое время. Об этом свидетельствуют древние погребенные долины. Глубина этих еще мало изученных долин указывает на то, что в границах территории Әстонии базис эрозии лежал временами значительно ниже, чем в современное время, т. е. территория была приподнята значительно больше над уровнем моря, чем сейчас. Сравнение глубин древних долин, погребенных отчасти или полностью отложениями антрологенового периода, говорит о том, что в границах территории Эстонии в доголоценовое время базис эрозии лежал ниже современного не один раз. Әто показывает, что направление неотектонических движений неоднократно изменялось.

Здесь не рассмотрен еще целый ряд геологических процессов, которые играли также существенную роль в геологическом развитий территории в антропогеновом периоде. Например, деятельность текучих вод, осадконакопление в озерах, торфообразование, эоловый процесс, карстовый процесс и др. Но их значение в геологическом развитии территории антропогенового периода зависит во многом от тех факторов, которые были изложены выше. Поэтому при изучении геологии антропогенового периода необходимо особо учитывать влияние коренных пород, древнего рельефа, отложений и форм рельефа материкового льда, отложений и форм рельефа морского происхождения и неотектонических движений на образование отложений и форм рельефа, возникающих под влиянием других геологических процессов.

В дополнение к изложенному можно привести еще пример, который указывает на необходимость всестороннего изучения геологии антропогенового периода.

Для территории Эстонской ССР характерно значительное распространение торфяных залежей и болотных равнин. Торф является одним из ценных полезных ископаемых, а болотные равнины находят в последнее время все более широкое использование в сельском хозяйстве. В распространении и в геологическом развитии торфяных залежей и болотных равнин территории Эстонской ССР можно наметить некоторые закономерности. В возвышенной части территории имеется мало крупных торфяников, что обусловлено в основном благоприятными условиями для стока атмосферных осадков. На возвышенности Пандивере, где коренными породами являются карбонатные породы ордовика и силура, атмосферные осадки просачиваются вглубь по многим карстовым понорам; на средне-девонском плато стоку атмосферных вод благоприятствуют многие долины; кроме того, холмисто-моренный рельеф, преобладающий на древних возвышенностях, не способствует развитию крупных торфяников, в то время как бессточные ложбины между холмами благоприятствуют образованию большого числа небольших болот.

В низинной части Әстонии, наоборот, имеется много крупных торфяников, развитию которых способствует равнинный характер этой части территории, обусловленный деятельностью материкового льда и моря, а также характером залегания и строения ордовикских и силурийских карбонатных пород. Для низменной части территории, в границах которой гидрографическая сеть еще слабо развита, характерен слабый сток атмосферных осадков. Своеобразны условня развития болот, расположенных вокруг возвышенности Пандивере, - здесь мы встречаем много сравнительно крупных болот, развитие которых тесно связано с карстовыми 
водами возвышенности Пандивере, вытекающими у подножия возвышенности в виде многочисленных источников. Эти воды, не имея нормального стока, способствуют сильному заболачиванию местности.

На развитие торфяников имеют значительное влияние также неотектонические движения. На северо-западе, в условиях более интенсивного поднятия, уровень грунтовых вод со временем понижается или по меньшей мере не повышается, что создает условия, неблагоприятные для длительного развития низинных болот, и действительно здесь мы имеем маломощные торфы низинных болот. В центральной и юго-восточной части низинной Эстонии, где поднятие земной коры значительно меньше, наблюдается постепенное повышение поверхности грунтовых вод. Такие условия способствуют длительному развитию низинных болот, о чем говорит большая мощность торфа низинных болот в этой части территории.

Торфяные залежи могли образоваться в низинной части территории одновременно с постепенным освобождением территории от вод Балтийского моря. Так, торфяные залежи, образовавшиеся, например, на равнинах во время литориновой стадии Балтийского моря, сравнительно молодые, мощность тофра их менее значительна, чем более древних торфяных залежей.

При изучении торфяных залежей надо учитывать и изменения климата, имевшие место в течение голоценовой эпохи. Кақ показывают соответствующие исследования, развитие болот на территории Эстонии началось только в раннем голоцене, т. е. одновременно с общим улучшением климата. Приближение климата в начале среднего голоцена к морскому способствовало широкому развитию на территории Эстонии верховых болот. Изменение же климата в конце среднего голоцена в сторону усиления континентальности обусловило интенсивное разложение торфа. Торфообразованию благоприятствовало похолодание климата в начале позднего голоцена.

Вышеизложенное показывает, что при изучении геологического развития торфяных залежей и болотных равнин необходимо учитывать влияние коренных пород, древнего рельефа, неотектонических движений, отложений и форм рельефа материкового льда, морской деятельности и других геологических процессов, которые в том или ином направлении оказывали влияние на развитие болот. Для того чтобы понять закономерности распространения и развития болот, необходимо при их изучении пользоваться комплексным методом. Такой же подход необходим и при изучении всех других геологических элементов. При этом хорошие результаты могут быть получены, если изучать эти элементы по генетическим типам, учитывая геологическое развитие территории.

Поступила в редакцию 26 IV 1955 